Arch. histol. jap., Vol. 37, No. 4 (1975)

p. $335-341$

Department of Anatomy (Prof. H. FujITA), Hiroshima University School of Medicine,

Hiroshima, Japan

\title{
Electron Probe Microanalysis of the Dense Bodies of Human Blood Platelets
}

\author{
Kenichi TAKAYA
}

Received September 10, 1974

Summary. Air-dried spreads of human blood platelets were prepared by incubating a drop of fresh blood from finger tips on collodion membrane covered copper grid for 4 min at $37^{\circ} \mathrm{C}$. The blood was blotted with filter paper and dried in the air at room temperature. Under the electron microscope various substructures were observable in the attenuated cytoplasm of platelets without any treatment, i.e., fixation, embedding or staining. The granulomere of platelets revealed dense bodies of $200-300 \mathrm{~nm}$ diameter and smaller dense granules (about $50 \mathrm{~nm}$ ). Larger ovoid bodies with dense granules presumably corresponded to mitochondria and lysosomes. In the hyalomere there were vacuoles partly connected with surface of the platelet by a canalicule.

Using an energy dispersive type $X$-ray microanalyzer attached to a scanning transmission electron microscope, electron probe analysis detected high levels of calcium and phosphorus and an appreciable amount of chlorine in the dense bodies of platelets. The three elements were also detected in the smaller dense granule.

This technique offers some advantages for microanaly tic study of the chemical components of cell organelles including the simplicity of the procedure, disuse of liquids in specimen preparation which were possibly causing substance escape, and avoidance of cryosections usually causing ice crystal artifacts.

Many attempts have been made to study the distribution of diffusible substances at the electron microscopic level by electron probe microanalysis and autoradiography (Christensen, 1969, 1971; Appleton, 1969, 1974). Use of fresh freeze-dried ultrathin sections is an ideal approach but the preparation of sections completely free from artifacts due to ice crystal formation is technically difficult (CHRISTENSEN, 1969, 1971; Appleton, 1969, 1974; TaKaya, 1974).

The energy dispersive X-ray microanalyzer yields good recognition of the elements present though it is not satisfactory for elements lower than sodium in atomic number (Russ, 1972). The combination of a spectrometer with the electron microscope reveals the fine structures present and permits direct application of the electron beam of the analyzer to selected, identified areas of the specimen. This combination has been applied successfully to fixed and embedded sections (GreENAWALT and Carafoli, 1966; Hillman and Llinãs, 1974; Martin, Carson and Race; 1974, Oschman et al., 1974; Somlyo et al., 1974).

Electron microscope observation of freshly air dried platelets showed that the ultrastructure was well preserved. This led the author to analyze the dense bodies of platelets using the energy dispersive type X-ray microanalyzer and to examine the value of this technique. 


\section{Materials and Methods}

Drops of finger tip blood from a 36-year-old healthy male were collected on $2 \%$ collodion membrane-covered copper grids (400 meshes) which were supported on glass slides and incubated for $4 \mathrm{~min}$ at $37^{\circ} \mathrm{C}$. The blood was then blotted with filter paper and the grids were immediately air dried. They were observed under the electron microscope, Hitachi HS-7, with the acceleration voltage at $50 \mathrm{kV}$. Some of the grids were observed after they were immersed in $2.5 \%$ glutaraldehyde in $0.1 \mathrm{M}$ phosphate buffer for $2 \mathrm{hr}$ at $4^{\circ} \mathrm{C}$ to study the effect of fixation and 0.2 M EDTA disodium treatment on the dense bodies.

Analysis was made of freshly air dried platelets on the copper grids with an energy dispersive X-ray microanalyzer (Nuclear Diodes, EDAX) equipped with a scanning transmission attachment (ASID) to the electron microscope (JEM-100C) with the acceleration voltage at $60 \mathrm{kV}$. The electron beam spot was approximately $200 \AA$ in diameter. X-ray counting time was about $180 \mathrm{sec}$. For the purpose of this report, two isolated platelets on the collodion membrane were analyzed including 6 dense bodies, one small electron dense round granule, two spots between bodies and two spots in the field outside of the platelets.
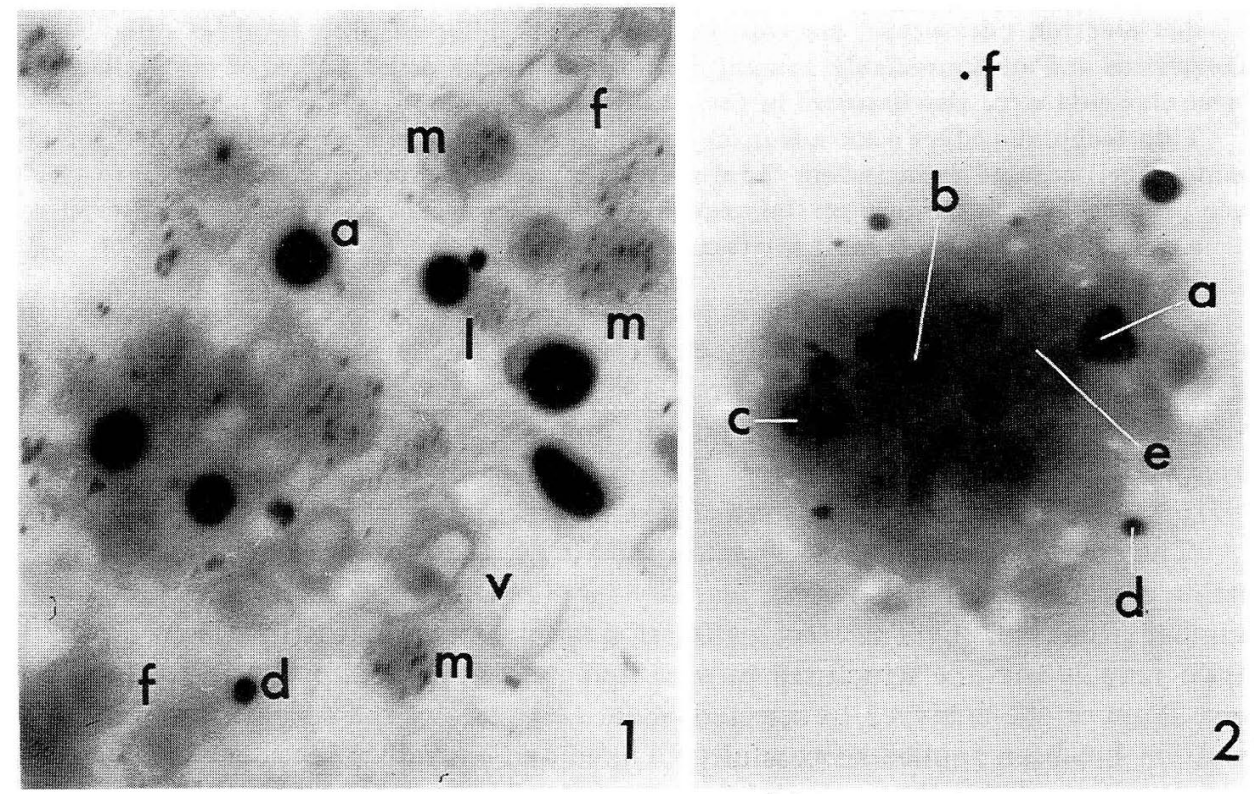

Fig. 1. Granulomere of a freshly air dried human platelet observed with a Hitachi HS-7 electron microscope with acceleration voltage at $50 \mathrm{kV}$. a Dense body, $d$ smaller dense granule, $f$ structures with a dense core surrounded by a halo and a membrane, $m$ and $l$ structures containing fine dense granules corresponding to mitochondria and lysosomes, $v$ vesicles. $\times 30,000$

Fig. 2. A whole human platelet spread on the collodion membrane covered copper grid observed by X-ray microanalyzer, with the acceleration voltage at $60 \mathrm{kV} . a, b, c$ Dense bodies examined by the electron probe, $d$ smaller electron dense granule, $e$ an area in the granulomere between dense bodies, $f$ a spot outside of the platelet, which probably contains plasma substances. $\quad \times 25,000$ 


\section{Observations and Results}

Electron microscopy of the freshly air dried platelets revealed that fine structures, especially in the granulomere were well preserved. Dense bodies (200-300 nm in diameter) were easily identified by their conspicuous electron density. Some had an irregular contour and others were smooth. Smaller spherical granules, about $50 \mathrm{~nm}$ in diameter, were also scattered in the granulomere. They had the same electron density as the dense bodies.

There were medium electron dense bodies oval in profile which were slightly larger than the dense bodies. They contained abundant fine irregularly shaped electron dense granules, $200-300 \AA$ in diameter. These bodies presumably corresponded to lysosomes and mitochondria. There were other bodies of unknown nature somewhat smaller than the oval ones, round or elongate in shape and surrounded by a membrane-like structure. Some had a halo between the membrane and the medium

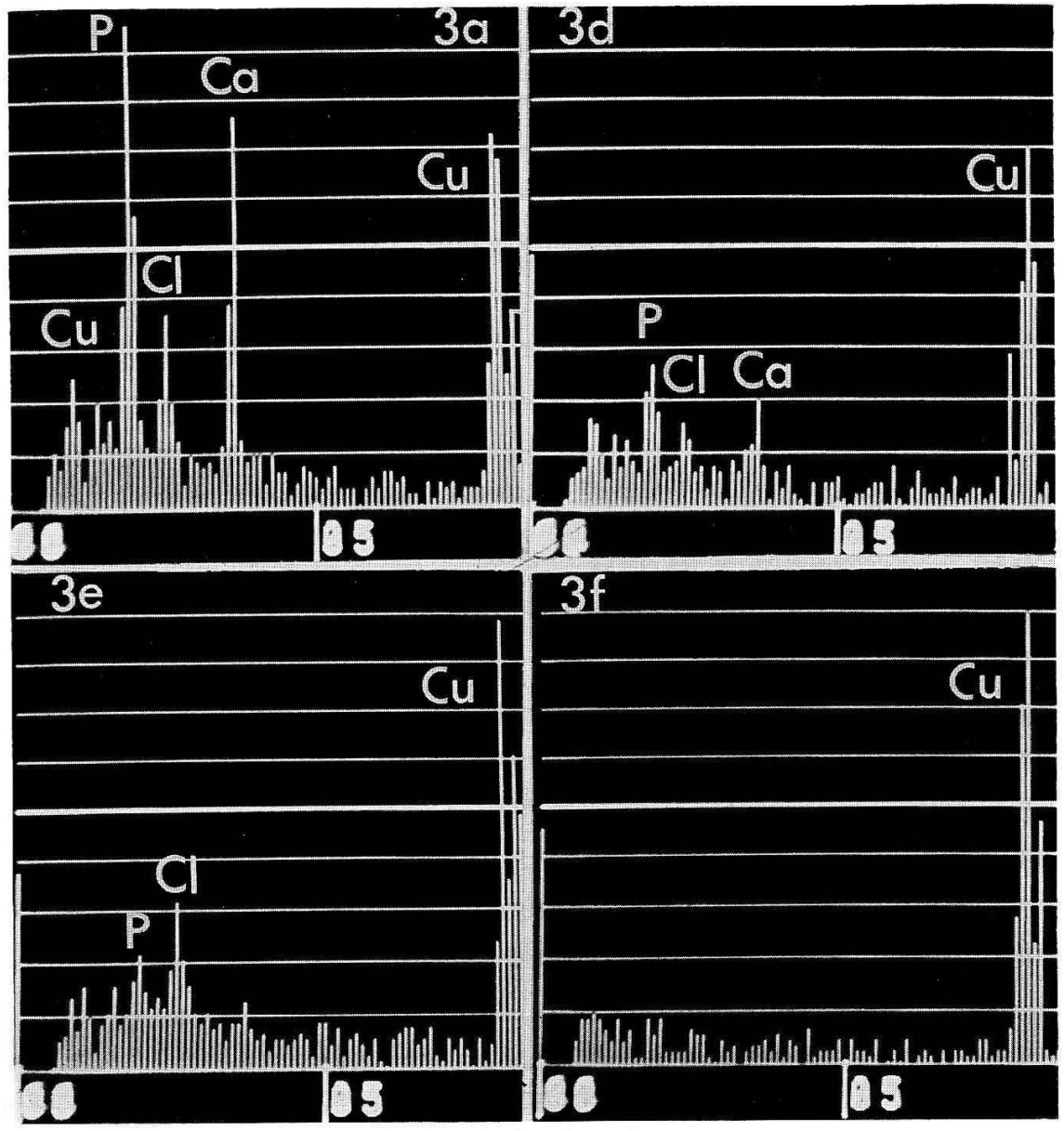

Fig. 3. Spectrographic analysis of the spots. $a, d, e$ and $f$ : Spots in the platelet shown in Figure 2. 
electron dense core which was situated eccentrically. There were numerous round or oval and rod-like vesicles which presumably corresponded to the dense duct system of the platelets (CAWLEY and HAYHOE, 1973). In the hyalomere, several vacuoles were seen. A few had a narrow canal connecting to the outer surface of the platelets. They probably corresponded to the surface connecting system (CAWLEY and НАYнOE, 1973).

Glutaraldehyde fixation of freshly air dried platelets induced the disappearance of the dense bodies in the isolated platelets, leaving electron lucent areas presumably corresponding to the sites of the dense bodies. When platelets were aggregated and not discrete, many of the dense bodies were still present. Complete disappearance of the dense bodies, which were confirmed to be present after glutaraldehyde fixation, was induced by the later treatment with $0.2 \mathrm{M}$ EDTA disodium solution.

Analysis of the dense bodies in freshly air dried platelets by X-ray microanalyzer disclosed distinct high peaks for calcium and phosphorus and appreciable peaks for chlorine (Fig. 3a). Analysis of six typical dense bodies in two isolated platelets showed that they had the same peaks for the three elements. Figures $2 \mathrm{a}, \mathrm{b}$ and $\mathrm{c}$, indicate the dense bodies in one of the platelets examined by electron probe. One of the smaller dense granules (Fig. 2d) also had peaks for calcium, phosphorus and chlorine (Fig. 3d). The relative height of these peaks was similar to that of dense bodies, suggesting that they are identical in nature. Two spots between the dense bodies revealed small peaks of phosphorus and chlorine (Fig. 2e; Fig. 3e), although the respective substructures could not be resolved by the present method of scanning transmission electron microscopy. Two spots outside the platelets showed no peaks for the specific elements. One of them is shown in Figures $2 \mathrm{f}$ and $3 \mathrm{f}$.

\section{Discussion}

Electron microscopy of air dried platelets disclosed well preserved cytoplasmic bodies which corresponded to organalles observed in conventional thin sections. The contents of these structures also were presumed to be well preserved.

Ethylenediaminetetraacetate (EDTA) is a sequestering agent and combines with most divalent and trivalent metal ions forming metal chelates soluble in water (The Merk Index, 1963). It is used to remove calcium in blood. Calcium-EDTA is also used to remove the other metal ions in blood by replacing them with calcium. In the present experiment dense bodies disappeared by EDTA disodium treatment, leaving the lucent areas corresponding to the sites of dense bodies. It might indicate that metal ions are concerned with the preservation of the dense substances in the bodies or that metals are contributing to the density of the bodies. The latter possibility is more likely from the present experiment by X-ray microanalysis.

Large amounts of calcium and phosphorus and appreciable amounts of chlorine were detected in the dense bodies of the platelets. Although this type of microanalyzer does not give exact quantitative results, it does charaterize the elements present and affords a semiquantitative comparison of their amounts. An appreciable amount of chlorine and phosphorus was detected in the granulomere between the dense bodies. This may represent cytoplasmic content of these elements. Since the dense bodies are surrounded by cytoplasm, some portion of the chlorine and phosphorus peaks could be ascribed to the cytoplasm. However, comparison of the height of the pulses 
from the dense bodies and from the two spots between them indicates that phosphorus and chlorine are contained in the dense bodies.

It is not possible, however, to determine with this method what chemical combinations these elements have in the dense bodies. It is speculated that they combine with each other or with receptor proteins and are concerned with the storage of amines in the dense bodies (COSTA, REESE and Murphy, 1974). High content of phosphorus might be explained by ATP in the dense bodies (Michal and Firkin, 1969). Also interesting is the report that calcium binding protein in the pig brain is phosphoprotein (WolfF and Siegel, 1972).

Dense bodies of freshly air dried platelets have attracted much attention (BuLL, 1966; White, 1969; Costa, Reese and Murphy, 1974). Costa, Reese and Murphy (1974) estimated the storage-packet size of serotonin in the dense bodies of platelets using platelet rich plasma. The dense bodies of platelets have been considered as a model in the study of the mechanism of storage and secretion of monoamines in other granules including adrenomedullary granules and synaptic vesicles of adrenergic nerve terminals. Large amounts of calcium and phosphorus were found in the dense bodies of the platelets from platelets rich plasma and the ratio between the calcium and phosphorus content was estimated by electron probe analysis (Costa, MurPhy and TANAKA, 1974).

By electron probe examination calcium and phosphorus have been demonstraed in 5-HT dense bodies in glutaraldehyde fixed and osmium postfixed platelets after microincineration of epon sections (MARTIN, CARsON and RACE, 1974). The 5-HT dense bodies probably are the same as the dense bodies which were preserved after fixation, especially in those piled up platelets described in this study. It should be noted that glutaraldehyde solution was buffered with phosphates and that the 5-HT dense granules have been shown to be influenced by the calcium in the media. The elements, calcium and phosphorus, detected in the 5-HT dense bodies of the platelets, presumably are modified somewhat in their chemical compositions from those present in circulating platelets. Use of the freshly air dried platelets taken directly from fresh blood may avoid this problem.

The absence of peaks for other elements in the dense bodies by the X-ray microanalyzer method does not necessarily mean that they are not present. They could be present in so small an amount that they would not be detected by this type of microanalyzer or they might be lost during and after the preparation of the specimens.

Addendum. After submission of this manuscript, we noticed that Skaer, Peters and Emmines (J. Cell Sci. 15: 679-692, 1974) reported the occurrence of calcium, phosphorus and chlorine in the dense bodies of platelets in the freeze-dried sections but they used embedding medium for sectioning.

Acknowledgement. Thanks are due to the facilities provided by Dr. H. Yотsumoto, JEOL Laboratory, Akishima, Tokyo, to work with the X-ray microanalyzer. The author is also grateful to Dr. A. STEER for checking English usage in the manuscript. 


\title{
新鮮乾燥伸展標本を用いた人血小板暗調小体 (dense bodies) のエネルギー分散型 $\mathbf{X}$ 線マイクロアナライザーによる分析
}

\author{
高 屋 憲 一
}

新鮮血をコロジオン膜をはった銅製グリッド上で保温 $\left(4\right.$ 分間 $\left.37^{\circ} \mathrm{C}\right)$ すると，血小板 は伸展して薄くなる. これを空気乾燥すると, 電子顕微鏡下にいろいろな微細構造がよ く保存されている. Granulomere には高密度の暗調小体（200-300 nm 直径）とより小 型で同様な密度をもつ小体（約 $50 \mathrm{~nm}$ 直径）が見られる。そのほか, やや大型で高密度 の顆粒をもつ小体は, 系粒体とリソゾームに相当すると思われる.さらに若干の小体 が記載された. Hyalomere には空胞があり，細管で細胞表面とつながっているものも見 られる。

エネルギー分散型X線マイクロアナライザーを用いて分析を行なつた結果, 大小両型 の暗調小体に多量のカルシウムと燐および いくらかの塩素が含まれることが明らかと なった。これらの元素の化学的な結合状態は不明であるが, 生体塩基貯蔵に意義あるも のと思う. この方法は他の組織にも広く応用可能と思われる.

\section{References}

Appleton, T. C.: Possibilities of locating soluble labeled compounds by electron microscope autoradiography. In: (ed. by) L. J. Roth and W. E. Stumpf: Autoradiography of diffusible substances. New York-London, Academic Press, 1969 (p. 301-319).

—- A cryostat approach to ultrathin 'dry' frozen sections for electron microscopy: a morphological and X-ray analytical study. J. Microsc. 100: 49-74 (1974).

Bull, B.: The ultrastructure of negatively stained platelets: Some physiological implications. Blood 28: 901-912 (1966).

Cawley, J. C. and F. G. J. Hayhoe: Ultrastructure of haemic cells. London-Philadelphia-Toronto, Saunders, 1973 (p. 44-49).

Christensen, A. K.: A way to prepare frozen thin sections of fresh tissue for electron microscopy. In: (ed. by) L. J. Roth and M. E. Stumpf: Autoradiography of diffusible substances. New York-London, Academic Press, 1969 (p. 349-362).

- Frozen thin sections of fresh tissue for electron microscopy with a description of pancreas and liver. J. Cell Biol. 51: 772-804 (1971).

Costa, J. L., D. L. Murphy and Y. Tanaka: Storage of calcium in human platelets: Estimation of storage-packet size. Fed. Proc. 33: No. 3, Part 1. (1974).

Costa, J. L., T. S. Reese and D. L. Murphy: Serotonin storage in platelet: Estimation of storagepacket size. Science 183: 537-538 (1974).

Greenawalt, J. W. and E. Carafoli: Electron microscope studies on the active accumulation of $\mathrm{Sr}^{++}$by rat liver mitochondria. J. Cell Biol. 29: 37-61 (1966).

Hillman, E. and R. Llinãs: Calcium containing electron-dense structures in the axons of the squid giant synapse. J. Cell Biol. 61: 146-155 (1974).

Martin, J. H., F. L. Carson and G. J. Race: Calcium-containing platelet granules. J. Cell Biol. 60: 775-777 (1974).

Michal, F. and B. G. Firkin: Physiological aspects of the platelet. Annu. Rev. Pharmacol. 9: 95118 (1969). 
Oschman, J. L., T. A. Hall, P. D. Peters and B. J. Wall: Association of calcium with membranes of squid giant axon. Ultrastructure and microprobe analysis. J. Cell Biol. 61: 156-165 (1974).

Russ, J. C.: Energy-dispersive analysis of X-rays and the scanning electron microscope. In: (ed. by) J. C. Russ: Thin-section microanalysis. Proceeding of a Symposium held on Nov. 8, 1972 in St. Louis. EDAX Lab., 1972 (p. 7-32).

Somlyo, A. P., A. V. Somlyo, C. E. Devine, P. D. Peters and T. A. Hall: Electron microscopy and electron probe analysis of mitochondrial cation accumulation in smooth muscle. J. Cell Biol. 61: 723-742 (1974).

Takaya, K.: Preparation of fresh frozen dried ultrathin sections and the interpretation of their figures using the unstained Epon sections and freshly air-dried tissue spread. (Abstract). J. Electron Microsc. 23: 219 (1974).

White, J. G.: The dense bodies of human platelets: inherent electron opacity of the serotonin storage particles. Blood 33: 598-606 (1969).

Wolff, D. J. and F. L. Siegel: Purification of a calcium-binding phosphoprotein from pig brain. J. Biol. Chem. 247: 4180-4185 (1972).

高屋憲一

干734 広島市霞 1-2-3

広島大学医学部

第二解剖学教室
Kenichi TAKaya

Department of Anatomy

Hiroshima University School of Medicine

Kasumi, Hiroshima, 734 Japan 